\title{
Future forest distribution on Finnmarksvidda, North Norway
}

\author{
Stein Rune Karlsen ${ }^{1, *}$, Hans Tømmervik ${ }^{2}$, Bernt Johansen ${ }^{1}$, Jan Åge Riseth ${ }^{1}$ \\ ${ }^{1}$ Norut Northern Research Institute, PO Box 6434, 9294 Tromsø, Norway \\ ${ }^{2}$ Norwegian Institute for Nature Research, FRAM - High North Centre for Climate and the Environment, \\ PO Box 6606 Langnes, 9296 Tromsø, Norway
}

\begin{abstract}
Finnmarksvidda is Norway's largest mountain plateau, located in the Arctic/alpineboreal transition area. The area is also a central winter grazing area for the reindeer herds of the indigenous Sámi people. This study develops a bioclimatic-based model to simulate future potential vegetation, with a focus on forest types. The model utilizes a bioclimatic study in the region, where vegetation types have been grouped according to minimum summer temperature demands. This is then used as a base for modelling of future vegetation. Due to the flat landscape of Finnmarksvidda, the model shows that a $1^{\circ} \mathrm{C}$ increase in summer temperatures will potentially lead to an increase of forested areas by $4485 \mathrm{~km}^{2}$, which is a $70 \%$ increase from the current $6900 \mathrm{~km}^{2}$ to a simulated $11706 \mathrm{~km}^{2}$. This in turn will lead to a reduction of Arctic-alpine heaths from $4440 \mathrm{~km}^{2}$ today to potentially only $670 \mathrm{~km}^{2}$. Such changes will have consequences for the reindeer grazing system, as the predicted changes will lead to a decrease in the vegetation types that have high winter grazing accessibility for reindeer, from $2386 \mathrm{~km}^{2}$ today to potentially only $377 \mathrm{~km}^{2}$. On the other hand, vegetation types with medium accessibility will experience an increase, from 2857 to $3366 \mathrm{~km}^{2}$.
\end{abstract}

KEY WORDS: Climate warming $\cdot$ Bioclimatic model $\cdot$ Temperature driver $\cdot$ Future forest $\cdot$ Treeline $\cdot$ Reindeer herding

\section{INTRODUCTION}

A predicted and to some extent realized consequence of global warming is the spread of shrub and birch forests to the Arctic tundra and its low-alpine fringes (e.g. Hofgaard et al. 2013). Recent research results show that shrub encroachment and tree invasion on the northern Fennoscandian tundra have been more rapid than previously expected (Kullman 2002, Tømmervik et al. 2009), and these changes are mainly human-driven and occurring concurrently with climatic change (Tømmervik et al. 2009, Hofgaard et al. 2013). Finnmarksvidda is Norway's largest mountain plateau and is located in the low alpine-northern boreal transition zone in northern Norway. This area therefore might potentially undergo considerable vegetation changes in terms of increased forest cover in a future

${ }^{*}$ Corresponding author: stein.rune.karlsen@norut.no

${ }^{\S}$ Advance View was available online May 18, 2017 warming climate with summer temperatures as the main driver. Finnmarksvidda is also the central area for the indigenous Sámi people's reindeer herds. The Sámi people with their reindeer herds utilize the differences in vegetation composition between the coast and Finnmarksvidda situated further inland when they move their herds according to the changing seasons. In winter, reindeer graze the alpine lichen heaths in the interior, and in spring, they move to the coast and take advantage of the early greening, grazing on herbs and grasses (Johansen \& Karlsen 2005). Shifts in the vegetation composition affect this finely tuned reindeer grazing system (Tømmervik et al. 2012, Riseth et al. 2016). In particular, the spread of birch and pine forests to the Arctic and alpine parts will greatly influence the amount of lichen. During the last decades, there has been evidence of altitudinal

() The authors 2017. Open Access under Creative Commons by Attribution Licence. Use, distribution and reproduction are unrestricted. Authors and original publication must be credited.

Publisher: Inter-Research · www.int-res.com 
and latitudinal advances in forest limits in northern Fennoscandia (Tømmervik et al. 2009, Aune et al. 2011, Van Bogaert et al. 2011, Hofgaard et al. 2013, Franke et al. 2015). However, the pattern is not clear, and these studies also indicate that it is difficult to separate the climatic drivers that lie behind the forest advances from other drivers, and the advances are possibly more dependent on the grazing regime. Understanding the response of terrestrial ecosystems to climatic warming is a challenging task because of the complex interactions of drivers such as climate, disturbance and recruitment across the landscape. Hence, the transition from alpine heaths to boreal forests is potentially controlled by many drivers that include climate, soil substrate changes, grazing, topography and disturbance, and may be expressed as either gradual or abrupt spatial changes (see e.g. Sveinbjörnsson et al. 2002, Holtmeier \& Broll 2007). An attempt using dynamic vegetation modelling (LPJGUESS model) for the Barents Region (Wolf et al. 2008) overestimated the forest abundance for the northern parts of the Kola Peninsula (Wolf et al. 2008). This modelling was carried out using a very coarse vegetation map (Olson Ecosystem map; spatial resolution of $0.5^{\circ} \times 0.5^{\circ}$ grid). Hence, by studying the modelling maps from this study for Finnmark county, Norway, an overestimation of the forest abundance also seems to be the case, since this part of the Barents Region has more rugged and high mountainous terrain that includes steep barren mountains and glaciers, where no tree can sprout and survive. One of the most difficult challenges in projecting vegetation dynamics from climate change is the development of rules for vegetation responses to climate.

This study aims to create a bioclimatic-based model to simulate potential future vegetation and forest distribution on Finnmarksvidda. This is done by utilizing a bioclimatic study of the region (Karlsen et al. 2005), where the vegetation types have been grouped according to minimum summer temperature demands and then used as a base for modelling future vegetation, where a method for this has recently been developed (Sjögren et al. 2015). Next, we also discuss some possible impacts on the reindeer winter grazing system.

\section{MATERIALS AND METHODS}

\subsection{Study area and current treeline}

Finnmarksvidda is situated in the low-alpinenorthern boreal transition ecotone between $68-70^{\circ} \mathrm{N}$

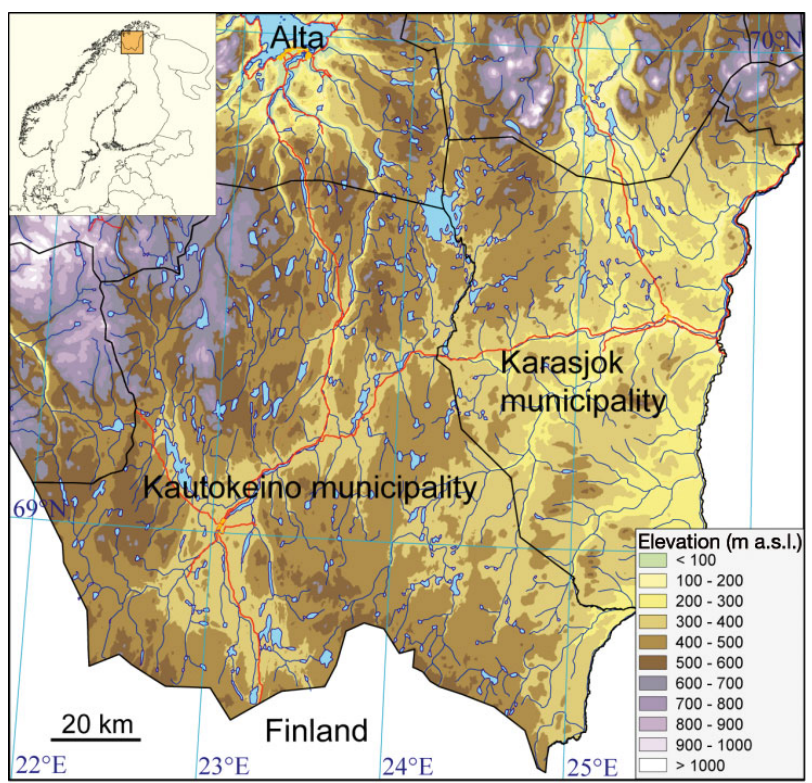

Fig. 1. An elevation model of the study area, Finnmarksvidda in northern Norway (inset: Fennoscandia). Current tree line is formed by birch and is between 420 and $480 \mathrm{~m}$ altitude

and $22-26^{\circ} \mathrm{E}$ (Fig. 1). The municipalities Karasjok (5453 $\mathrm{km}^{2}$ ) and Kautokeino (9708 $\mathrm{km}^{2}$ ) constitute most of this plateau. The Precambrian bedrock of Finnmarksvidda was reshaped by glacier activity during the Pleistocene era and is covered with a moraine layer, which forms a flat and gentle landscape with nutrient-poor soils such as podzols and nanopodzol (Lindström 1987). The current treeline is made up of birch Betula pubescens and varies a lot across Finnmarksvidda. It lies as low as $360 \mathrm{~m}$ altitude in the central north and can reach up to $520 \mathrm{~m}$ altitude in the southwestern parts, where it is common to find individual trees even at $600 \mathrm{~m}$ altitude. However, most often, the treeline lies between 420 and $480 \mathrm{~m}$ altitude. In most cases, on dry and nutrient-poor soil, the treeline gradually changes from open multi-stemmed birch forest to dwarf birch heaths (Tømmervik et al. 2009). In Karasjok and Kautokeino, as much as 22 and $63 \%$ of the municipalities are between 400 and $600 \mathrm{~m}$ altitude, respectively. Hence, large parts of Finnmarksvidda are situated between the birch treeline and the birch forest line.

\subsection{Previous, present and future climate}

Finnmarksvidda has a continental climate where the meteorological stations in the villages Karasjok and Kautokeino show a mean July temperature 
(standard normal 1961-1990) of 13.1 and $12.4^{\circ} \mathrm{C}$, respectively (Aune 1993). The mean annual precipitation is $366 \mathrm{~mm}$ in Karasjok and $325 \mathrm{~mm}$ in Kautokeino (Førland 1993), with about half of the precipitation falling between June and August. During the last century, the Finnmarksvidda summer temperature has shown a trend of about $0.07^{\circ} \mathrm{C}$ increase per decade (Vikhamar-Schuler et al. 2010, HanssenBauer et al. 2015). Precipitation has been variable, with wet summers in the mid-1960s and in the last 2 decades. The length of the phenologically defined growing season is in the range of 90-130 d (Karlsen et al. 2008), without any clear trends during the last decades (Høgda et al. 2013). The future scenarios for Finnmarksvidda indicate an increase in summer (June, July, August) temperature in the range of $2-5.5^{\circ} \mathrm{C}$ by the end of this century compared with the 1971-2000 period, depending on the scenario used (Hanssen-Bauer et al. 2015). The prediction for summer precipitation (Hanssen-Bauer et al. 2015) is in the range of $15-24 \%$ increase, while it is $13-14 \%$ increase for winter precipitation (December, January, February).

\subsection{Simulation of potential future forest distribution}

Recently, a bioclimatic-based method was developed to model vegetation backwards in time (Sjögren et al. 2015). In this study, we apply the method to model potential future vegetation on Finnmarksvidda, with a focus on forest types. The starting point of the modelling is the result from an extensive bioclimatic study on Varangerhalvøya, northeast Norway. On the peninsula, methods for using plant species and vegetation types have been developed and applied (Karlsen \& Elvebakk 2003, Karlsen et al. 2005). The bioclimatic methods for climatic mapping are based on the fact that most plant species and plant communities both in the Arctic and adjacent areas have to some extent a distribution pattern limited by growing season temperature. Varangerhalvøya is a peninsula located approximately $150 \mathrm{~km}$ east-northeast of Finnmarksvidda, and most of the results from the peninsula can be transferred to the study area. The vegetation on the peninsula was first mapped using Landsat TM satellite data, and then the mapped vegetation units were defined as temperature indicators based on their total distribution patterns and the temperature indicator value of their high frequency and dominant species, as found by relevé analysis. Vegetation units were grouped according to their minimum temperature requirements in terms of mean July temperature. Vegetation types were also grouped according to their habitat preferences. In this study, we started with a Landsat TM-based vegetation map from Finnmarksvidda (Johansen \& Karlsen 2007). This map was then compared with vegetation units that had been previously grouped according to their minimum temperature requirements in terms of mean July temperature mapped on Varangerhalvøya (Karlsen et al. 2005). All mapped vegetation types on Finnmarksvidda, except pine (Pinus sylvestris) forests and lichen (Cladonia spp.) heaths, have related types on Varangerhalvøya. Mires were excluded from the study due to their large variation in species composition and fine mosaic structures that are not easily detected by Landsat TM satellite data. The mapped vegetation types on Finnmarksvidda were then grouped according to their minimum temperature preferences, with increments of $1^{\circ} \mathrm{C}$ difference in mean July temperature. Also, the pine forest types and lichen heaths were forced into temperature and habitat groups, by judgement of species composition found by literature studies (Wehberg 2007).

After the grouping of all vegetation types (except for mires) had been carried out according to minimum temperature and habitat preferences, we proceeded to the next step, which involved analysing the altitude distribution of all vegetation types in relation to the closest treeline today. The current treeline is formed by birch and varies across the study area. Based on the forest data supplied by the Norwegian Mapping Authority (N50 data) and modified by hyperclustering-based classification (Hofgaard et al. 2013), polylines of the upper treeline were extracted with the use of ArcGIS software. We then compared the upper treeline with a terrain model and created a gridline raster where each pixel was assigned altitude information. Since these gridlines only covers small parts of the study area, we interpolated the data (kriging) to create a raster that covers the whole study area, where each pixel was assigned a value corresponding to the altitude of the closest upper treeline. To avoid outliers when determining the current upper limit of the different vegetation types, we used the height limit where $95 \%$ of the area covered by each vegetation types occurred. The final step was to simulate future vegetation expected from increased July temperature. The simulation was performed using Python scripts in the ArcGIS software. We assumed that a $1^{\circ} \mathrm{C}$ change in July temperature would correspond to a $171 \mathrm{~m}$ change in altitude of the treeline, based on a temper- 
ature change of $0.585^{\circ} \mathrm{C}$ per $100 \mathrm{~m}$. We also assumed that current temperature-dependent (thermophilous) vegetation types would expand into colder areas and replace less temperature-dependent vegetation types with equal habitat preferences. For instance, a blueberry-birch forest type (which requires approximately $10^{\circ} \mathrm{C}$ mean July temperature) will replace a blueberry-crowberry alpine heath (which requires approximately $9^{\circ} \mathrm{C}$ mean July temperature). Both vegetation types occur on mesic habitats. In cases with no climatic/habitat counterparts, the vegetation types were reclassified to coarser units. The simulation is regulated such that the replacement from one group to another must not exceed a $171 \mathrm{~m}$ altitude change per $1{ }^{\circ} \mathrm{C}$ change in mean July temperature. For instance, if a forest type at present reaches $100 \mathrm{~m}$ below the current treeline, it will potentially reach $71 \mathrm{~m}$ above the current treeline with a $1^{\circ} \mathrm{C}$ increase in mean July temperature. Finally, all mapped and modelled units were judged according to winter reindeer grazing accessibility (cf. Johansen \& Karlsen 2005, 2007).

\section{RESULTS}

\subsection{Present vegetation cover}

The present and potential future vegetation cover on Finnmarksvidda is illustrated in Fig. 2. Table 1 shows the present and future cover of the modelled vegetation types for Karasjok and Kautokeino municipalities respectively. Fig. 3 summarizes the changes in forest distribution, and at present, forest covers $62 \%$ of the total area in Karasjok and $36 \%$ in Kautokeino. In Karasjok, birch is the most common forest type, but at lower altitudes, pine and mixed birchpine forests are also present. In Kautokeino, the forests consist almost completely of birch. Alpine heaths and meadows cover $25 \%$ in Karasjok and $43 \%$ in Kautokeino, while mires cover 10 and $16 \%$ respectively. Vegetation types with high or medium winter grazing accessibility covers $25 \%$ of the total area in Karasjok and $40 \%$ in Kautokeino (Table 1).

\subsection{Potential future vegetation cover}

The results of the simulation indicate potentially dramatic changes in vegetation cover due to temperature increase (Table 1, Figs. 2 \& 3). In Karasjok, forest-covered areas will potentially increase from 62 to $84 \%$. Such changes will cause a reduction in heaths and meadows from 25 to only $3 \%$. In particular, the pine forest and mixed pine-birch forests types will increase in Karasjok. In Kautokeino, forested areas will double from 36 to $74 \%$, and correspondingly, alpine heaths and meadows will be reduced from $43 \%$ cover to $5 \%$. The mixed pine-birch forest will increase from 1.5 to $18 \%$ cover. Lichen-rich
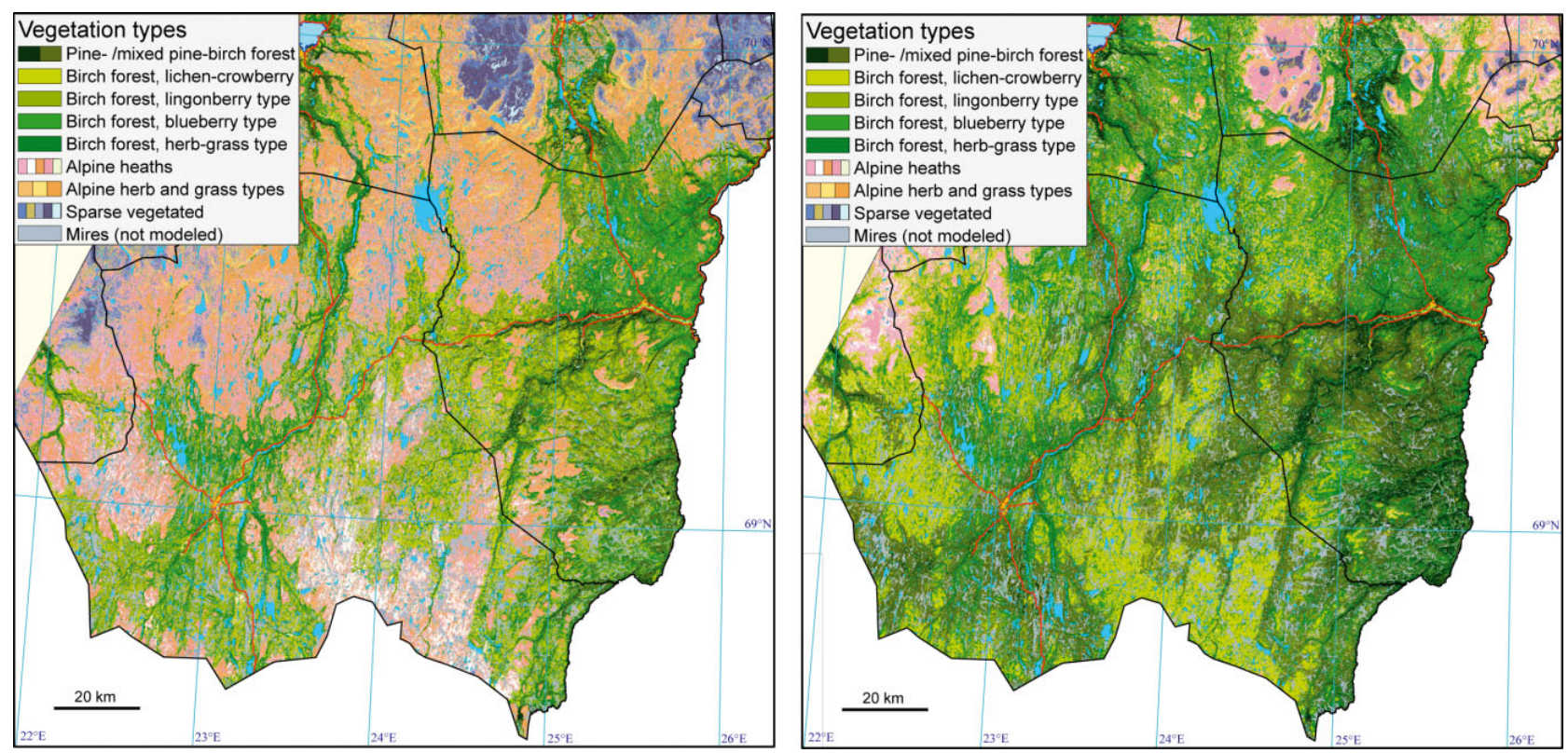

Fig. 2. Left: current vegetation, redrawn from Johansen \& Karlsen (2007). Right: scenario map showing simulated potential forest distribution at $1^{\circ} \mathrm{C}$ increase of July temperature 
Table 1. Current and simulated potential future cover of main vegetation units in Karasjok and Kautokeino municipalities. The cover of current (year 2006) main vegetation units is extracted from Johansen \& Karlsen (2007). The area of simulated potential future cover is based on $1^{\circ} \mathrm{C}$ increase of mean July temperature. Mire types are not included in the simulation

\begin{tabular}{|c|c|c|c|c|c|c|c|c|c|}
\hline & \multirow{3}{*}{$\begin{array}{l}\text { Winter grazing } \\
\text { accessibility } \\
\text { for reindeer }\end{array}$} & \multicolumn{4}{|c|}{ Karasjok } & \multicolumn{4}{|c|}{ Kautokeino ${ }^{-}$} \\
\hline & & \multicolumn{2}{|c|}{ Present } & \multicolumn{2}{|c|}{$+1^{\circ} \mathrm{C}$} & \multicolumn{2}{|c|}{ Present } & \multicolumn{2}{|c|}{$+1^{\circ} \mathrm{C}$} \\
\hline & & $\mathrm{km}^{2}$ & $\%$ & $\mathrm{~km}^{2}$ & $\%$ & $\mathrm{~km}^{2}$ & $\%$ & $\mathrm{~km}^{2}$ & $\%$ \\
\hline Pine forests & Medium & 205 & 3.8 & 697 & 12.8 & 184 & 1.9 & 321 & 3.3 \\
\hline Mixed pine-birch forest & Low & 549 & 10.1 & 1432 & 26.3 & 145 & 1.5 & 1768 & 18.2 \\
\hline Birch forest, open lichen-crowberry type & Medium & 484 & 8.9 & 353 & 6.5 & 1002 & 10.3 & 1947 & 20.1 \\
\hline Birch forest, dense lingonberry type & Low & 1070 & 19.6 & 474 & 8.7 & 1146 & 11.8 & 1060 & 10.9 \\
\hline $\begin{array}{l}\text { Birch forest, mesic type, blueberry and } \\
\text { grass-dominated }\end{array}$ & Low & 524 & 9.6 & 661 & 12.1 & 343 & 3.5 & 620 & 6.4 \\
\hline Birch forest, herb and grass-dominated & Low & 562 & 10.3 & 979 & 18.0 & 686 & 7.1 & 1394 & 14.4 \\
\hline Exposed heaths & High & 336 & 6.2 & 30 & 0.6 & 1462 & 15.1 & 218 & 2.2 \\
\hline Lichen heaths & High & 24 & 0.4 & 26 & 0.5 & 564 & 5.8 & 103 & 1.1 \\
\hline Crowberry-dwarf birch heaths & Medium & 301 & 5.5 & 9 & 0.2 & 681 & 7.0 & 39 & 0.4 \\
\hline Fresh heaths and meadows & Low & 576 & 10.6 & 56 & 1.0 & 1037 & 10.7 & 167 & 1.7 \\
\hline Unvegetated/sparsely vegetated & & 105 & 1.9 & 17 & 0.3 & 391 & 4.0 & 5 & 0.1 \\
\hline Mires (not modelled) & & 556 & 10.2 & 556 & 10.2 & 1527 & 15.7 & 1527 & 15.7 \\
\hline Water & & 154 & 2.8 & 154 & 2.8 & 533 & 5.5 & 533 & 5.5 \\
\hline Total & & 5447 & 100.0 & 5447 & 100.0 & 9702 & 100.0 & 9702 & 100.0 \\
\hline
\end{tabular}

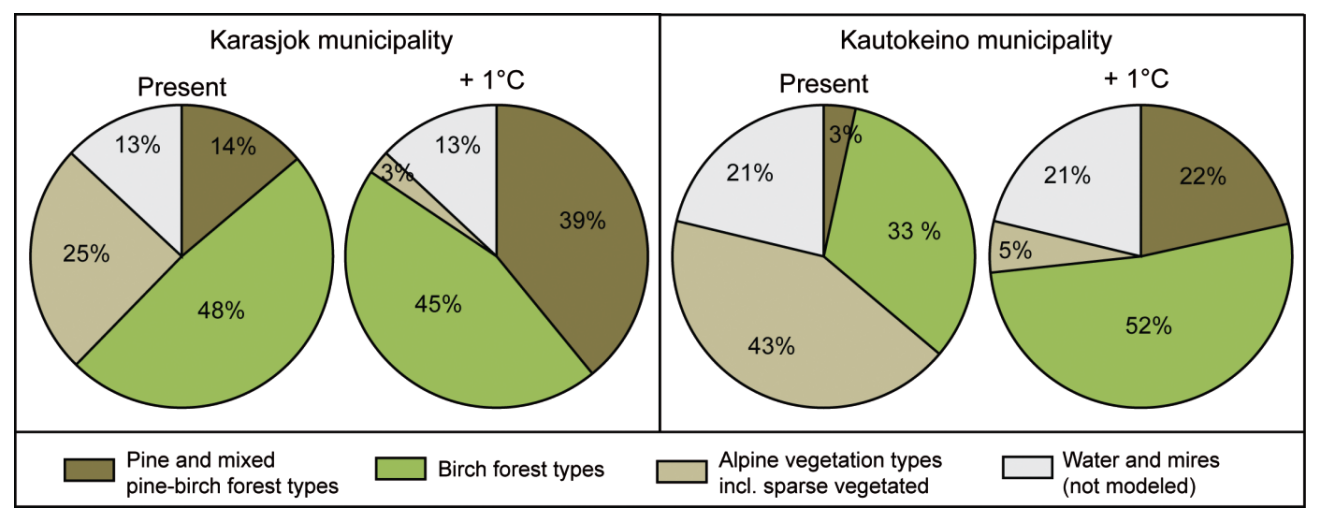

Fig. 3. Present and potential future $\left(1^{\circ} \mathrm{C}\right.$ increase of July temperature) forest distribution in Karasjok (left) and Kautokeino (right) municipalities, extracted from Table 1

crowberry (Empetrum hermaphroditum)-birch forest and grass and herb-rich birch forest will also approximately double their cover (Table 1). In total for Karasjok and Kautokeino, forested areas will increase by $4485 \mathrm{~km}^{2}$, which corresponds to a $70 \%$ increase from $6900 \mathrm{~km}^{2}$ at present to a simulated $11706 \mathrm{~km}^{2}$. This will also lead to a reduction of mountain heaths from $4440 \mathrm{~km}^{2}$ at present to potentially only $670 \mathrm{~km}^{2}$. These changes will result in a dramatic decrease in vegetation types with high winter grazing accessibility from $2386 \mathrm{~km}^{2}$ today to potentially only $377 \mathrm{~km}^{2}$. Vegetation types with low winter grazing accessibility will increase in area by $3010 \mathrm{~km}^{2}$ (from 5601 to $8611 \mathrm{~km}^{2}$ ). The area covered by vegetation types with medium winter grazing accessibility will also increase from 2857 to $3366 \mathrm{~km}^{2}$.

\section{DISCUSSION}

\subsection{Reliability of simulation of future forest distribution}

The modelling in this study indicates that a dramatic increase in the distribution of the forests on Finnmarksvidda may take place with only a $1^{\circ} \mathrm{C}$ increase in mean July temperature. This modelled change will completely change all aspects of the ecosystems on Finnmarksvidda, by having effects on biodiversity, energy exchange, reindeer husbandry and other land use. However, can this be true? It is challenging to develop rules for vegetation response to climate change. To simulate changes in tree cover and vegetation, advanced models like the ALFRESCO 
model in Alaska (Rupp et al. 2000a,b) have been developed, which take into account several drivers like temperature, precipitation, seed dispersal and fire. Or for example the dynamic vegetation modelling framework LPJ-GUESS, which is designed to simulate global and regional dynamics and composition of vegetation in response to changes in climate, atmospheric $\mathrm{CO}_{2}$ concentration and nitrogen deposition (Smith et al. 2001, 2014). On the other hand, an example of a very simple model uses only a terrain model and altitudinal replacement, assuming that the current forest distribution is in equilibrium with temperature and would change with increased summer temperature. Such a model is used for simulation of future forest distribution in current alpine areas of Sweden (Moen et al. 2004). A similar reasoning is also common when inferring past temperatures from pollen records in Fennoscandia (Seppä \& Hicks 2006). Temperature as a determinant of tree distributions is a question of scale (e.g. Holtmeier \& Broll 2005). The importance of temperature on a global scale is clearly reflected in the gradual descent of the treeline from its maximum altitudinal position in the subtropics towards the pole. Grace et al. (2002) show that temperature seems to limit forest growth more significantly than it limits photosynthesis over the temperature range $5-20^{\circ} \mathrm{C}$. If we assume that growth and reproduction of birch are controlled by temperature, an advance of the birch treeline would be predicted. Grace et al. (2002), Lucht et al. (2002) and Hofgaard et al. (2013) have provided evidence using remotely sensed data that suggest that this is occurring. Our results presented in Figs. 2 \& 3, showing the simulated potential increase of forested areas in the future, are in agreement with these authors. On a local scale, hydrology/snow or rather, topography and substrate texture governing hydrology, are probably the most decisive drivers determining the distribution of plants. This study works on a regional scale with pixel size on $30 \mathrm{~m}$ and hence drivers other than temperature influence the forest distribution. In addition to temperature, our modelling also takes into account available habitats. The model is thereby able to simulate the future distribution of 5 main forest types. This also ensures for instance that it is not possible for forest to grow into an area that is currently without soil, since soil formation is a slow process in the mountains. However, the role that trees themselves have on the environment is not taken into account. Trees affect the physical and edaphic conditions. New trees will change soil and hydrological properties and thereby change the habitats. Trees may also increase snow distribution and accumula- tion, reduce wind, nutrient conditions and energy exchange, since trees and shrubs reduce surface albedo (e.g. Sveinbjörnsson et al. 2002, Holtmeier \& Broll 2007, de Wit et al. 2014). Still, it is reasonable to believe that summer temperature is the main limiting factor. Evidence that Finnmarksvidda was most likely covered by forests in warmer periods during the Holocene (Høeg 2000, Seppä \& Hicks 2006, Huntley et al. 2013) support this view.

There is already a general trend towards more forest cover on Finnmarksvidda. During the last decades, the vegetation cover has changed dramatically on Finnmarksvidda; lichen heaths have been reduced and birch forest has increased (Tømmervik et al. 2004, 2009, 2012, Johansen \& Karlsen 2005, 2007, Hofgaard et al. 2013). This is mainly due to changes in grazing pressure by reindeer. The removal of 'the barrier effect' of the thick lichen coverage (Sedia \& Ehrenfeld 2003) by heavy reindeer grazing and trampling provides open sites that makes it easier for birch seeds to germinate and sprout (Houle \& Filion 2003, Tømmervik et al. 2004). Eskelinen \& Virtanen (2005) stated that natural grazing by reindeer favours species colonization and seedling emergence. This has in turn led to the establishment of clusters of trees and subsequent forests (Houle \& Filion 2003, Tømmervik et al. 2004). Furthermore, this has led to an elevation of the forest upper boundary by the filling in of the gap between the 'old' forest line and the treeline with forest (Sveinbjörnsson et al. 2002, Tømmervik et al. 2004). On the other hand, intense reindeer grazing can have negative impacts and cause erosion, and seedling establishment can be hampered by drought (e.g. Holtmeier 2012). However, factors other than temperature and grazing may have influenced these changes. Increased precipitation, which has occurred on Finnmarksvidda during the last few decades, is also important (Tømmervik et al. 2009). Another important disturbance factor influencing growth at the treeline in the region is insect defoliation resulting from outbreaks of geometrid moths (Tenow et al. 2007, Jepsen et al. 2009). Such outbreaks may cause treeline retreat. Finnmarksvidda experienced large outbreaks in both 2004 and 2005 (Bjerke et al. 2014), which may have influenced the treeline locally (authors' pers. obs., Holtmeier 2012). However, disturbances such as moth outbreaks (Karlsen et al. 2013) and winter warming (Bokhorst et al. 2009, Bjerke et al. 2014) might also lead to more rapid birch forest growth as it may damage crowberry Empetrum hermaphroditum, which possibly prevent birch seeds germinating and sprouting (Nilsson \& Zackrisson 
1992, Bråthen et al. 2010). In contrast to the described effects of reindeer grazing on lichen pastures in the winter grazing areas, the effects on herbs, willows and trees in summer pasture areas are quite different, as reindeer can stabilize and move the treeline downwards (Cairns \& Moen 2004, Cairns et al. 2007, Tømmervik et al. 2009), and also promote the growth of rare mountain plants (Olofsson \& Oksanen 2005). Prevailing disturbance regimes in the coastal parts of Finnmark are to a large extent species-specific, but directly or indirectly related to climate (Hofgaard et al. 2013). Also, grazing by reindeer, moose, cows and sheep might prevent shrubification and forest advance (Tømmervik et al. 2009, Hofgaard et al. 2013). In particular, this is evident for birch forests on the coast and the near-coast inland. However, at the coast, the reduced number of cattle and sheep during the last decades have increased the forest cover in these areas (Fylkesmannen i Finnmark 2012, Hofgaard et al. 2013).

\subsection{Lagged response to climate change}

We are then left with the question: when will the modelled increase in forest distribution happen? How long is the lagged response? Our modelling indicates the direct magnitude of the change, but reveals little about the rate and pattern of change. Due to the flat landscape of Finnmarksvidda and the large variation in the altitude of the treeline, the main increase in forest distribution in our modelling largely results from the filling in of gaps between the existing trees and tree groups, and to a lesser extent from the establishment of trees at sites above the present tree limit. It is reasonable to believe that this will happen gradually and that the altitudinal shift of the treeline may lag behind climate change on a timescale of decades. There will likely be local differences whereby changes will take place according to variations in soil conditions, insect outbreaks, winter warming effects, precipitation and grazing pressure.

Pine has a slower growth rate and dispersal rate than birch and therefore responds on an even longer timescale (Kellomäki \& Kolström 1994). Spruce (Pica abies) forests occur at nearby locations in northern Finland. Possible future spruce forests were not included in the modelling, since a northward advance could be inhibited by factors other than summer temperature, such as soil properties or other climatic factors (Siren 1955, Oksanen 1995, Sutinen et al. 2005).

In a synthesis study on tundra and treeline ecosystems, Epstein et al. (2004) found that in the Seward
Peninsula in Alaska, most of the species present in the shrub tundra communities above the treeline are also present in the understory of forested areas, and that the transition from tundra to forested vegetation therefore typically involves gradual changes in tree density and morphology. It is reasonable to believe that a similar development occurs on Finnmarksvidda. Also from the Seward Peninsula study, it was shown by simulation using the AFRESCO model that under a $2^{\circ} \mathrm{C}$ warming scenario, there would be a time lag of $70-290 \mathrm{yr}$ for the doubling of the initial total forest cover to take place (Rupp et al. 2000b). However, the simulation was performed for spruce forest and a $2^{\circ} \mathrm{C}$ increase, while the development of birch forest in Finnmarksvidda might occur faster, perhaps on a time frame of half a century. The relatively rapid and ongoing increase of birch forest cover has also been shown by Hofgaard et al. (2013). These analyses revealed an average northward advance of birch and pine latitudinal forest lines in northernmost Norway since the early $20^{\text {th }}$ century of 156 and $71 \mathrm{~m} \mathrm{yr}^{-1}$, respectively. This shows that birch has a more rapid northbound advance on the tundra than pine. However, the more rapid advance for birch than pine might partly be a result of extensive illegal logging, especially at the latitudinal pine treeline, but also at the latitudinal treeline, as discussed by Hofgaard et al. (2013). A focus on factors limiting the advance of certain species as well as the response of the forest-tundra ecotone to climate change are needed in order to refine the output from more dynamic regional and global vegetation models (e.g. Wolf et al. 2008).

\subsection{Impacts of future forests on reindeer grazing system}

The modelling of future vegetation cover indicates a dramatic change in forest distribution on Finnmarksvidda, and major parts of the open lichen heaths will change to woodland with less accessibility for winter reindeer grazing. This will impact the reindeer grazing system in several ways. Reindeer are adapted to utilize lichens as energy sources, which is sufficient to ensure survival if enough lichens are available. The establishment of forest on previous lichen and dwarf shrub-dominated heaths may increase snow accumulation and reduce wind (Holtmeier \& Broll 2007). This in turn typically tends to create more compact types of snow in forests, making penetrability of the snow pack, and hence grazing due to lower accessibility, gradually more diffi- 
cult as the winter proceeds (Collins \& Smith 1991, Heggberget et al. 2002, Riseth et al. 2011). Therefore, snow conditions are crucial in determining the availability of the lichens, and in particular, late-season ice-crust formations may have strong effects on the condition and survival of the animals (Moen 2008). Snow hardness, snow depth and animal mobility are also factors affecting reindeer selection of feeding areas (Collins \& Smith 1991). Greater snow depths in forests makes digging of grazing hollows more demanding and energy-consuming, and thus requires relocation to a more open landscape (Sara 1999). Accordingly, birch expansion increases the grazing pressure on the remaining open tundra and sparsely populated pine and birch forest area, since the relocation will need to be conducted at an earlier stage of the winter. On the other hand, greater snow depths might hinder grazing and promote lichen growth, especially on heavily grazed areas in the forests (Tømmervik et al. 2009).

Acknowledgements. This study is mainly financed by The Norwegian Reindeer Administration Authorities, 'Development Fund of Reindeer Husbandry', and in part by the Nordic Centre of Excellence (NCoE) project 'Climatechange effects on the epidemiology of infectious diseases and the impacts on Northern Societies (CLINF)'. This article is based upon work from COST Action ES1203 SENSFOR, supported by COST (European Cooperation in Science and Technology). We thank Dr. Hannah Vickers for the English editing.

\section{LITERATURE CITED}

Aune B (1993) Temperaturnormaler, normalperiode 19611990. Klima rapp 02/93. Det Norske Meteorologiske Institutt, Oslo

Aune S, Hofgaard A, Söderström L (2011) Contrasting climate- and land-use-driven tree encroachment patterns of subarctic tundra in northern Norway and the Kola Peninsula. Can J For Res 41:437-449

Bjerke JW, Karlsen SR, Høgda KA, Malnes E and others (2014) Record-low primary productivity and high plant damage in the Nordic Arctic Region in 2012 caused by multiple weather events and pest outbreaks. Environ Res Lett 9:084006

Bokhorst SF, Bjerke JW, Tømmervik H, Callaghan TV, Phoenix GK (2009) Winter warming events damage subArctic vegetation: consistent evidence from an experimental manipulation and a natural event. J Ecol 97: 1408-1415

Bråthen KA, Fodstad CH, Gallet C (2010) Ecosystem disturbance reduces the allelopathic effects of Empetrum hermaphroditum humus on tundra plants. J Veg Sci 21: 786-795

Cairns D, Moen J (2004) Herbivory influences tree lines. $\mathrm{J}$ Ecol 92:1019-1024

Cairns D, Lafon C, Moen J, Young A (2007) Influences of animal activity on treeline position and pattern: implica- tions for treeline responses to climate change. Phys Geogr 28:419-433

Collins WB, Smith TS (1991) Effects of wind-hardened snow on foraging by reindeer (Rangifer tarandus). Arctic 44: 217-222

de Wit HA, Bryn A, Hofgaard A, Karstensen J, Kvalevåg M, Peters GP (2014) Climate warming feedback from mountain birch forest expansion: reduced albedo dominates carbon uptake. Glob Change Biol 20:2344-2355

* Epstein HE, Beringer J, Gould WA, Lloyd AH and others (2004) The nature of spatial transitions in the Arctic. J Biogeogr 31:1917-1933

* Eskelinen A, Virtanen R (2005) Local and regional processes in low-productive mountain plant communities: the roles of seed and microsite limitation in relation to grazing. Oikos 110:360-368

Førland JE (1993) Nedbørsnormaler, normalperiode 19611990. Klima rapp 39/93. Det Norske Meteorologiske Institutt, Oslo

Franke AK, Aatsinki P, Hallikainen V, Huhta E and others (2015) Quantifying changes of the coniferous forest line in Finnish Lapland during 1983-2009. Silva Fennica 49: 1408

Fylkesmannen i Finnmark (2012) Skog- og klimaprogram for Finnmark 2013-2016. Fylkesmannen i Finnmark, Vadsø

Grace J, Berninger F, Nagay L (2002) Impacts of climate change on the tree line. Ann Bot 90:537-544

Hanssen-Bauer I, Førland EJ, Haddeland I, Hisdal H and others (2015) Klima i Norge 2100. NCCS rep no. 2/2015. Norsk klimaservicesenter, Oslo

*Heggberget TM, Gaare E, Ball JP (2002) Reindeer (Rangifer tarandus) and climate change: importance of winter forage. Rangifer 22:13-32

*Høeg HI (2000) Pollenanalytiske undersøkelser i Finnmark, Nord Norge. AmS-Varia 37:53-97

*Hofgaard A, Tømmervik H, Rees G, Hanssen F (2013) Latitudinal forest advance in northernmost Norway since the early 20th century. J Biogeogr 40:938-949

*Høgda K, Tømmervik H, Karlsen SR (2013) Trends in start of the growing season in Fennoscandia 1982-2011. Remote Sens 5:4304-4318

Holtmeier FK (2012) Impact of wild herbivorous mammals and birds on the altitudinal and northern treeline ecotones. Landsc Online 30:1-28

*Holtmeier FK, Broll G (2005) Sensitivity and response or northern hemisphere altitudinal and polar treelines to global environmental change at landscape and local scales. Glob Ecol Biogeogr 14:395-410

Holtmeier FK, Broll G (2007) Treeline advance-driving processes and adverse factors. Landsc Online 1:1-33

*Houle G, Filion L (2003) The effects of lichens on white spruce seedling establishment and juvenile growth in a spruce-lichen woodland of subarctic Quebec. Ecoscience 10:80-84

*Huntley B, Long AJ, Allen JRM (2013) Spatio-temporal patterns in Lateglacial and Holocene vegetation and climate of Finnmark, northernmost Europe. Quat Sci Rev 70: 158-175

Jepsen JU, Hagen SB, Høgda KA, Ims RA, Karlsen SR, Tømmervik HA, Yoccoz NG (2009) Monitoring the spatiotemporal dynamics of geometrid moth outbreaks in birch forest using MODIS NDVI. Remote Sens Environ 113: 1939-1947

Johansen B, Karlsen SR (2005) Monitoring vegetation changes on Finnmarksvidda, Northern Norway, using Landsat 
MSS and Landsat TM/ETM+ satellite images. Phytocoenologia 35:969-984

Johansen B, Karlsen SR (2007) Finnmarksvidda - kartlegging og overvåkning av reinbeiter - status 2006. Norut IT Rapp IT394/1-2007. Norut, Tromsø

Karlsen SR, Elvebakk A (2003) A method using indicator plants to map local climatic variation in the Kangerlussuaq/Scoresby Sund area, East Greenland. J Biogeogr 30:1469-1491

Karlsen SR, Elvebakk A, Johansen B (2005) A vegetationbased method to map climatic variation in the arcticboreal transition area of Finnmark, north-easternmost Norway. J Biogeogr 32:1161-1186

Karlsen SR, Tolvanen A, Kubin E, Poikolainen J and others (2008) MODIS-NDVI based mapping of the length of the growing season in northern Fennoscandia. Int J Appl Earth Obs Geoinf 10:253-266

Karlsen SR, Jepsen JU, Odland A, Ims RA, Elvebakk A (2013) Outbreaks by canopy-feeding geometrid moth cause state-dependent shifts in understorey plant communities. Oecologia 173:859-870

Kellomäki S, Kolström M (1994) The influence of climate change on the productivity of Scots pine, Norway spruce, pendula birch and Pubescent birch in southern and northern Finland. Forest Ecol Manag 5:201-217

Kullman L (2002) Rapid recent range-margin rise of tree and shrub species in the Swedish Scandes. J Ecol 90:68-77

Lindström M (1987) Northernmost Scandinavia in the geological perspective. Ecol Bull 38:17-37

Lucht W, Prentice IC, Myneni RB, Sitch S and others (2002) Climatic control of the high-latitude vegetation greening trend and Pinatubo effect. Science 296:1687-1689

Moen J (2008) Climate change: effects on the ecological basis for reindeer husbandry in Sweden. Ambio 37:304-311

* Moen J, Aune K, Edenius L, Angerbjörn A (2004) Potential effects of climate change on treeline position in the Swedish mountains. Ecol Soc 9:16

Nilsson MC, Zackrisson O (1992) Inhibition of Scots pine seedling establishment by Empetrum hermaphroditum. J Chem Ecol 18:1857-1870

Oksanen L (1995) Isolated occurrences of spruce, Picea abies, in northernmost Fennoscandia in relation to the enigma of continental mountain birch forests. Acta Bot Fennica 153:81-92

O Olofsson J, Oksanen L (2005) Effects of reindeer density on vascular plant diversity on North Scandinavian mountains. Rangifer 25:5-18

Riseth JÅ, Tømmervik H, Helander Renvall E, Labba N and others (2011) Sámi TEK as a guide to science: snow, ice and reindeer pasture facing climate change. Polar Rec 47:202-217

Riseth JÅ, Tømmervik H, Bjerke JW (2016) 175 years of adaptation: North Scandinavian Sámi reindeer herding between government policies and winter climate variability (1835-2010). J For Econ 24:186-204

Rupp TS, Starfield AM, Chapin FS III (2000a) A frame-based spatially explicit model of subarctic vegetation response to climate change: comparison with a point model. Landsc Ecol 15:383-400

Rupp TS, Chapin FS III, Starfield AM (2000b) Responses of subarctic vegetation to transient climatic change on the Seward Peninsula in north-west Alaska. Glob Change Biol 6:541-555

Sara MN (1999) Praktisk reinbeitebruk — tradisjonelle kunn- skaper. Rangifer Rep 3:93-102

* Sedia EG, Ehrenfeld JG (2003) Lichens and mosses promote alternate stable plant communities in the New Jersey Pinelands. Oikos 100:447-458

Seppä H, Hicks S (2006) Integration of modern and past pollen accumulation rate (PAR) records across the arctic tree-line: a method for more precise vegetation reconstructions. Quat Sci Rev 25:1501-1516

Siren G (1955) The development of spruce forest on raw humus sites in Northern Finland and its ecology. Acta Forest Fennica 62, No. 4, article ID7453

* Sjögren P, Karlsen SR, Jensen C (2015) The use of quantitative models to assess long-term climate-vegetation dynamics - a case study from the northern Scandinavian Mountains. Holocene 25:1124-1133

* Smith B, Prentice IC, Sykes MT (2001) Representation of vegetation dynamics in the modelling of terrestrial ecosystems: comparing two contrasting approaches within European climate space. Glob Ecol Biogeogr 10:621-637

Smith B, Warlind D, Arneth A, Hickler T, Leadley P, Siltberg J, Zaehle S (2014) Implications of incorporating N cycling and $\mathrm{N}$ limitations on primary production in an individualbased dynamic vegetation model. Biogeosciences 11: 2027-2054

Sutinen R, Hyvönen E, Ruther A, Ahl A, Marja-Liisa Sutinen ML (2005) Soil-driven timberline of spruce (Picea abies) in Tanaelv belt-Lapland granulite transition, Finland. Arct Antarct Alp Res 37:611-619

* Sveinbjörnsson B, Hofgaard A, Lloyd A (2002) Natural causes of the tundra-taiga boundary. Ambio Spec Rep $12: 23-29$

* Tenow O, Nilssen AC, Bylund H, Hogstad O (2007) Waves and synchrony in Epirrita autumnata/Operopthera brumata outbreaks. I. Lagged synchrony: regionally, locally and among species. J Anim Ecol 76:258-268

* Tømmervik $\mathrm{H}$, Johansen B, Tombre I, Thannheiser D, Høgda KA, Gaare E, Wielgolaski FE (2004) Vegetation changes in the Nordic mountain birch forest: the influence of grazing and climate change. Arct Antarct Alp Res 36:323-332

พ Tømmervik H, Johansen B, Riseth JÅ, Karlsen SR, Solberg B, Høgda KA (2009) Above ground biomass changes in the mountain birch forests and mountain heaths of Finnmarksvidda, Northern Norway, in the period 1957-2006. For Ecol Manage 257:244-257

Tømmervik H, Bjerke JW, Gaare E, Johansen B, Thannheiser D (2012) Rapid recovery of recently overexploited winter pastures for reindeer in northern Norway. Fungal Ecol 5:3-15

*Van Bogaert R, Haneca K, Hoogesteger J, Jonasson C, Dapper MD, Callagan TV (2011) A century of tree line changes in sub-Arctic Sweden shows local and regional variability and only a minor influence of 20th century climate warming. J Biogeogr 38:907-921

Vikhamar-Schuler D, Hanssen-Bauer I, Førland E (2010) Long-term climate trends of Finnmarksvidda, NorthernNorway. Met.no rep no. 6/2010. Norwegian Meteorological Institute, Oslo

Wehberg J (2007) Der Fjellbirkenwald in Lappland. Eine vegetationsökologische Studie. Mitt Geogr Ges Hamburg 99:1-215

Wolf A, Callaghan TV, Larson K (2008) Future changes in vegetation and ecosystem function of the Barents Region. Clim Change 87: 51

Submitted: April 8, 2016; Accepted: January 26, 2017

Proofs received from author(s): April 18, 2017 